\title{
Integration of Thermoelectric generators (TEG) in Solar PVT panels
} Ángel A. Bayod-Rújula ${ }^{1}$, Amaya Martínez-Gracia ${ }^{2}$, Alejandro Del Amo ${ }^{3}$, Marta Cañada ${ }^{3}$, Sergio Usón ${ }^{2}$, Javier Uche ${ }^{2}$, Juan A. Tejero ${ }^{1}$

${ }^{1}$ CIRCE Institute - Department of Electrical Engineering, University of Zaragoza. María de Luna St., 50018, Zaragoza, Spain Phone:+0034976 761920, e-mail: aabayod@unizar.es, jatejero@unizar.es

${ }^{2}$ CIRCE Institute - Department of Mechanical Engineering, University of Zaragoza. María de Luna St., 50018, Zaragoza, Spain

Phone:+0034 976 762565, e-mail: amayamg@unizar.es, suson@unizar.es, javiuche@unizar.es

${ }^{3}$ Abora Solar S.L. Advanced solar energy. Buenos Aires St, 117, 50196, La Muela, Zaragoza, Spain

Phone:+0034 876 247096, e-mail: adelamo@abora-solar.com, marta.canada@abora-solar.com

\begin{abstract}
Photovoltaic-thermal hybrid panels (PVT) simultaneously generate electricity and heat with a greater overall efficiency than photovoltaic (PV) and thermal (ST) panels independently. Hybrid PVT-TEG intends to go a step further by integrating thermoelectric modules (TEG) that, based on the Seebeck effect, produce electricity from a temperature difference, thus allowing an additional production of electricity and thus an increase of energy efficiency. In this paper, the design and construction of an experimental installation, consisting of two solar collectors PVT, one of them with 19 TEG modules integrated is presented. This prototype will allow to observe the increase in the electrical production that can be obtained by introducing TEG in PVT modules and the differences in the behaviour (yields and W/Q ratio) between modules with and without TEG.
\end{abstract}

\section{Key words}

Photovoltaic-thermal hybrid panels (PVT), Thermoelectric generators (TEG), Solar energy; Energy efficiency

\section{Introduction}

Solar energy has the potential to play a leadership in achieving a sustainable energy future high efficiency for society. The solar use is called to play an important role in fulfilling the requirements of the Directives 2010/31 / EU and 2012/27 / EU in terms of reducing the energy consumption of buildings and a greater penetration of energy systems renewable in buildings and in particular in the residential sector. Thermal-photovoltaic hybrid panels (PVT) simultaneously generate electricity and heat from a same opening area with a greater overall efficiency than a panel photovoltaic (PV) and thermal (ST) independent. Given that the residential sector represents $25 \%$ of electricity and $30 \%$ of final energy in the EU, its massive implementation can contribute significantly to these objectives. The electricity generated in the PVT can be consumed in local loads, stored in batteries or injected into the network. The heat can be used as hot water, air conditioning, heat pumps or cooling machines to produce absorption cooling or adsorción. Desalinated water can also be produced in situ at demand points with shortages (Mediterranean), also consuming heat or electricity (depending on the technology chosen), and with reasonable energy costs. With respect to the thermal energy produced, it is usually of low temperature, since the electrical performance is substantially reduced if it is operated above $40-50^{\circ} \mathrm{C}$.

This paper intends to go a step further by integrating thermoelectric modules (TEG) that, based on the Seebeck effect, produce electricity from a temperature difference, thus allowing an additional production of electricity and thus an increase of energy efficiency.

The TEG technology has several advantages that make it especially suitable for implementation in domestic polygeneration schemes: it is reliable, silent, requires low or no maintenance and is easily scalable. Among its drawbacks is its cost and its low efficiency for low temperature modules that can be minimized by careful thermal integration with hot and cold bulbs. The integration of the TEG in solar collectors or combustion equipment is an emerging research line as can be seen in the review of the state of the art of the matter.

Regarding the use of TEG integrated into PVT, there is a modelling and analysis [1-2], but the experience has been done in an installation that is not really a PVT [3].

It is possible to integrate TEG modules in PVT panels, but it is necessary to analyse how this integration influences their behaviour (electrical and thermal performances, as well as the $\mathrm{W} / \mathrm{Q}$ ratio), as well as where and under what operating conditions it is interesting to install them. Consequently, there is the 
need for experimentation works in which to experimentally analyse the degree of improvement of the adequate implantation of the TEG devices in the PVT panels and the influence on their performance with the incorporation of a TEG, since its inclusion implies a new thermal resistance that affects both the working temperatures of the photovoltaic cells as well as the absorber, and therefore the electrical and thermal performances. In addition, the low thermal jump between foci and the existence of a temperature gradient from the lower water inlet zone to the upper exit zone where the water is warmer, make it necessary to analyse the behaviour of the TEGs based on the conditions of operation in each zone of the panel, as well as the improvement that involves dividing the associations of TEG modules into subgroups within a panel, each with a system for monitoring the point of maximum independent power.

\section{Testing bench}

The design, construction and start-up of an experimental installation, consisting of two solar collectors PVT, one of them with 19 TEG modules integrated has been done. The objective is to observe the differences in the behaviours (performances and $\mathrm{W} / \mathrm{Q}$ ratio) between panels with and without TEG, with the usual operating temperatures in PVT systems. The experimental installation has a data acquisition system that allows simultaneous collection of meteorological data (irradiance, air velocity around the panels and room temperature), PVT panel data (liquid inlet and outlet temperatures, flow and pressure) and data of the TEG modules (average temperature of the TEG module, voltage and current output, load resistance and power extracted).

With this prototype the influence of the irradiance, ambient temperature and temperature of the fluid, (which is determined by parameters of the PVT system such as the size of the water tank and the existing demand) will be experimentally analysed. The tests will aim to determine the electricity production that can be obtained from the TEG in a facility for the different climatic situations (summer days, winter, with variable demands) that allow the extrapolation of results over a whole year, and therefore an analysis of the percentage increase in electricity generation that could be extracted with respect to a conventional PVT panel. Different areas in the PVT have been monitored to analyse the effect that the temperature gradient occurs along the panel is in the production of TEG. The fluid, which enters at a low temperature at the bottom, rises and heats up to the highest temperature at the top of the module.

The installation has two PVT's, the first is a type hybrid solar panel and the second incorporates in the interior a TEG integration and a recirculation of return fluid to achieve a temperature difference and produce electricity with these elements.

\subsection{Components of the hydraulic part}

- Heat exchanger: The selected tank is composed of an indoor coil for the exchange of energy between the primary circuit and the accumulation volume. The accumulation volume is 197 litres.

- Pumping group: Compact equipment that includes the circulation pump, safety valve, manometer, filling and emptying key, and thermometer.

- Control unit: The control unit is integrated in the pump group kit. This equipment controls the operation of the primary circuit depending on the deposit temperatures and PVT's. The operation programming is specified in the manual that is supplied with the equipment.

- 3-way valve: In case the control unit activates it, the heat transfer fluid will roast through the air heater and not through the tank.

- Air heater: Component that, if activated by the control unit, dissipates the heat of the heat transfer fluid.

- Flowmeter: The flow measurement is sent by pulses to the monitoring system and measures the general flow of the installation.

- Pressure sensor: Send the pressure data from the installation to the monitoring system.

- Temperature probes: The installation incorporates 2 types of temperature probes. The operating part contains a temperature probe in the tank and another in the interior of one of the PVT's in the upper part of it. The probes for the monitoring are located in the entrance and in the general exit of the PVT's.

- Bleeders: They are located in the upper parts of the installation and their opening is necessary in the filling of the installation.

- Isolation valves: At the entrance and exit of the elements of the installation, isolation valves are available to direct the fluid, depending on the test that is to be performed.

\subsection{Components photovoltaic subsystem}

- PVT modules: The Spanish modules PVT manufacturer company, (Abora-Advanced Solar Technology) has manufactured an experimental module adding the TEG modules in the panel PVT. The PVT used as base is the Second generation Abora FT AH60 with thermal insulation on the rear face and an insulating chamber on the front face of the panel (external dimensions $(\mathrm{LxAxE})=$ $1641 \times 992 \times 65 \mathrm{~mm}$ ) with a total area of $1.65 \mathrm{~m} 2$ and opening area of $1.57 \mathrm{~m} 2$ and weight $42 \mathrm{~kg}$. The photovoltaic layer is formed by 60 monocrystalline cells, with a maximum power in STC of $260 \mathrm{~W}$ and an electrical efficiency of $16.01 \%$, and the following electrical values:

$\mathrm{Vmp}=31.44 \mathrm{~V}, \mathrm{Imp}=8.59 \mathrm{~A}, \mathrm{Isc}=9.07 \mathrm{~A}, \mathrm{Voc}=38.65$ A, under standard conditions STC (AM 1.5, Irradiation $1000 \mathrm{~W} / \mathrm{m} 2$, cell temperature $25^{\circ} \mathrm{C}$ ).

The thermal characteristics are: estagnation temperature is $154.9^{\circ} \mathrm{C}$. Optical yield 0.59 , coefficient of losses primary $3.3 \mathrm{~W} / \mathrm{m} 2 * \mathrm{~K}$, secondary coefficient $0.018 \mathrm{~W} / \mathrm{m} 2 * \mathrm{~K}$.

- Connection box: A connection box with a positive and a negative cable is incorporated in the back of each PVT. The output of the positive and negative poles is connected directly to the microinverter independently. 


\begin{tabular}{ll}
\hline Especificaciones Generales & \\
\hline Largo x Ancho x Espesor & $1650 \times 995 \times 82 \mathrm{~mm}$ \\
AreaTotal & $1.65 \mathrm{~m}^{2}$ \\
Area de Apertura & $1.57 \mathrm{~m}^{2}$ \\
$N^{\circ}$ células & 60 \\
Peso & $45 \mathrm{~kg}$. \\
Vidrio Frontal & $3.2 \mathrm{~mm}$. templado \\
Marco & Aluminio \\
Protección Caja de Conex. & IP65 \\
No Diodos & 3 diodos \\
Dimensiones de célula & $156 \times 156$ \\
Tipo de conexión FV / Longitud cables & Solarlok PV4 / 1m \\
& \\
\hline
\end{tabular}

\begin{tabular}{|c|c|}
\hline \multicolumn{2}{|l|}{$\boxplus$ Especificaciones Eléctricas } \\
\hline \multicolumn{2}{|c|}{$\begin{array}{l}\text { Condiciones de prueba estándar STC: AM } 1.5 \text {, Irradiación } 1000 \mathrm{~W} / \mathrm{m}^{2} \text {, } \\
\text { temperatura de la célula } 25^{\circ} \mathrm{C} \text {. }\end{array}$} \\
\hline Tipo de célula & Mono-cristalina \\
\hline Potencia Nominal (W) & 260 \\
\hline Tensión Máxima Potencia (Vmpp) & $31.44 \mathrm{~V}$ \\
\hline Corriente Máxima Potencia (Impp) & $8.59 \mathrm{~A}$ \\
\hline Tensión Circuito Abierto (Voc) & $38.65 \mathrm{~V}$ \\
\hline Corriente Cortocircuito (Isc) & $9.07 \mathrm{~A}$ \\
\hline Eficiencia del módulo (\%) & 16.01 \\
\hline Tolerancia de Potencia (W) & $0 /+3 \%$ \\
\hline Tensión Máxima del Sistema & DC $1000 \mathrm{~V}(\mathrm{IEC})$ \\
\hline Backsheet & Negro \\
\hline Coeficiente de temperatura de Pmpp & $-0.43 \% /{ }^{\circ} \mathrm{C}$ \\
\hline Coeficiente de temperatura de Voc & $-0.34 \% /{ }^{\circ} \mathrm{C}$ \\
\hline Coeficiente de temperatura de Isc & $+0.03 \% /{ }^{\circ} \mathrm{C}$ \\
\hline Corriente inversa máxima & $15 \mathrm{~A}$ \\
\hline Temperatura $\mathrm{NOCT}^{*}$ & $45+1-2^{\circ} \mathrm{C}$ \\
\hline${ }^{\circ} 800 \mathrm{~W} / \mathrm{m} 2$, AM 1.5 , velocidad del viento $1 \mathrm{~m} / \mathrm{s} \mathrm{y}$ & $-20^{\circ} \mathrm{C}$ \\
\hline
\end{tabular}

\section{$\boxplus$ Especificaciones Térmicas}

Rendimiento óptico

Coef. Pérdidas Térmicas,a1

Coef. Pérdidas Térmicas,a2

Volumen liquido interior

Temperatura de estancamiento

Num. Conexiones hidráulicas

Medida Conexión hidráulica

Presión máxima admisible

\subsection{9}

3. $3 \mathrm{~W} / \mathrm{m}^{2} . \mathrm{K}$

$0.018 \mathrm{~W} / \mathrm{m}^{2} \cdot \mathrm{K}^{2}$

$1.5 \mathrm{~L}$

$154,9^{\circ} \mathrm{C}$

4 conexiones

conexionado rápido

10 bar

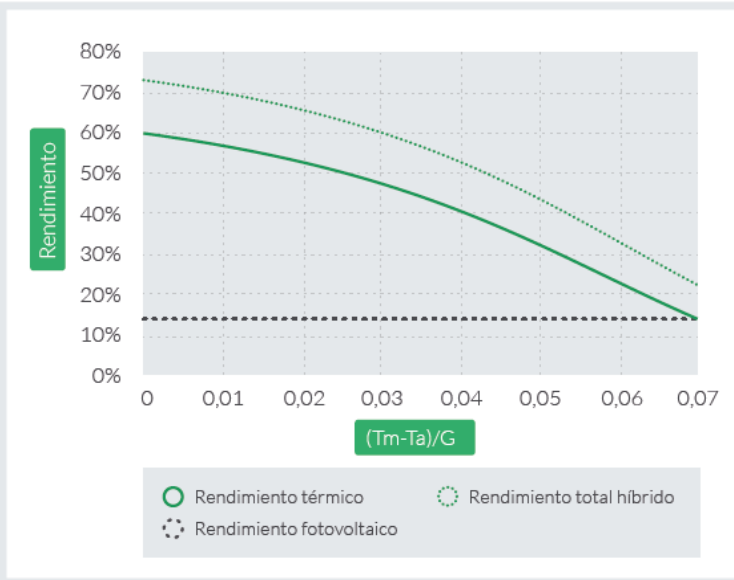

Fig. 1: Electrical, thermal and optical specifications of the PVT AH60

- Microinverter: A 530W microinverter with two positive and two negative dc connectors has been installed in the main frame of the bench and they. This single unit connects two solar modules because it presents an individual MPPT for each module (dual MPPT). Their MPPT Voltage Range is $22 \mathrm{~V}-45 \mathrm{~V}$ and they are recommended for PV Module Power (STC) in the range of $180 \mathrm{Wp}-310 \mathrm{Wp} / 60$ and $72-$ cell PV modules. The output in alternating current is connected to the necessary protections to be able to connect to the network.

- Protection: Before the output connector of the general panel, 2 fuses (1 per panel) are positioned in the form of alternating current protection. Once the current is transformed into alternating current, there is a differential and a thermal-magnetic protection.

Regardless of the electrical connection of the PVT's for generation of electricity, the equipment in the test bench requires electricity to operate. For this reason, from the bottom of the electrical panel, an electrical outlet has been enabled to power the components of the electrical panel and another connector in the hydraulic circuit control unit, located on the front of the tank. These sockets must be connected to the network in order to perform any action with the test bench prototype.

For the realization of the tests it is necessary that the entrance of water of the primary circuit passes through the interior of the PVT in which the TEG's are located, in this way we will be able to refrigerate and achieve the difference of temperature necessary to produce electrical energy

If a very low TEG cooling temperature is required, the tank must be at the lowest possible temperature. In case the tank temperature is high, low TEG cooling temperatures will not be achieved, since an energy exchange is made inside the coil. In the latter case, the tank can be emptied and water from the network introduced.

\section{- Monitoring system}

A monitoring system will measure and record irradiance, temperatures, flow rate and pressure of the solar hydraulic circuit as well as the voltage and electrical intensity (by means of a Hall effect probe) of the photovoltaic system. To do this, the device has been connected to HYBRID MONITOR 1.0. Through an online platform this information is available in any internet browser.

\section{PVT + TEG System}

In this section, integration of TEG elements inside a hybrid solar panel (PVT) is detailed. The main idea is to achieve a temperature difference inside the panel, placing the TEG between the pipe that collects the energy produced by the collector in the form of heat and another pipe through which the same fluid flows at a lower temperature. The hot side must be in excellent contact with a heat source and cold side must be thermally touching and compressed against a heat exchanger that can remove the heat effectively away from the cold side face of the module in order to create a large DT

To achieve the perfect integration and contact between elements at different temperatures and TEG, copper sheets have been used according to the required size, since the shape of the pipe is not in accordance with that of the TEG. 
The first operation consists in introducing a pipe in the existing PVT heat recuperator. In order to be able to integrate it inside the panel, a copper tube parallel to the upper collector is manufactured, and copper fins are welded, similar in size to the TEG.

The two pipes (through which water will circulate at different temperatures), are installed and then the fins welded., Next, the TEGs are placed, with their flat part in contact with the fins. To achieve a consistent hold between TEG and copper fins, pressure clamps placed on the back of each copper fin are used. The TEGs units are connected electrically in series, leaving the positive pole on one side of the panel, and the negative on the opposite side.

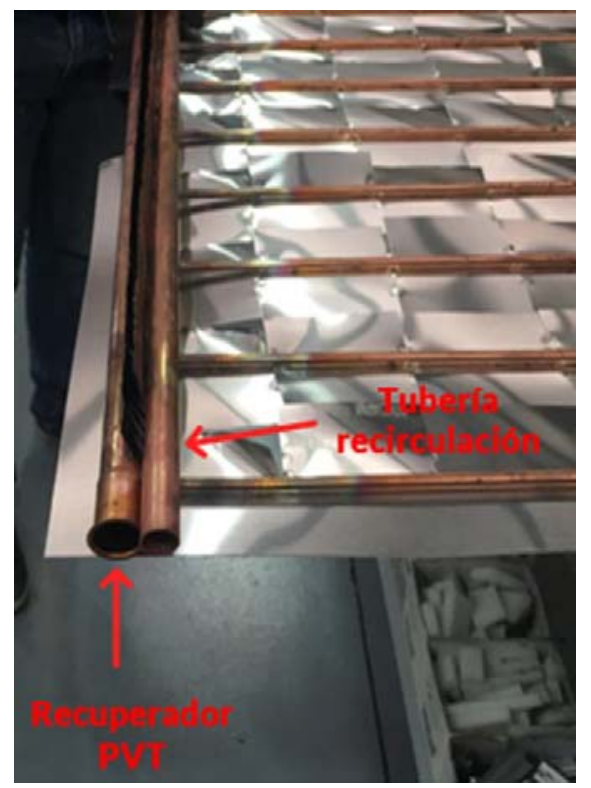

Figure 2: Detail of the copper tube parallel to the upper collector installation

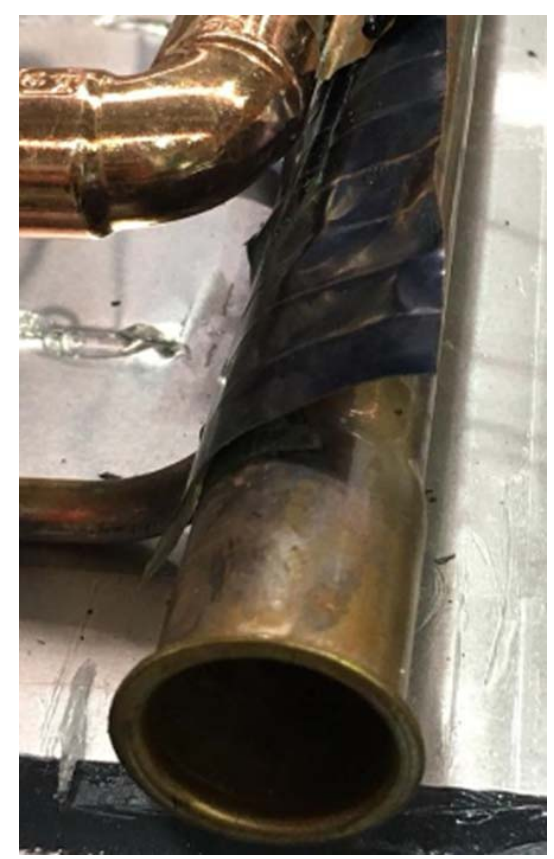

Fig.3: Placement of TEG between copper fins

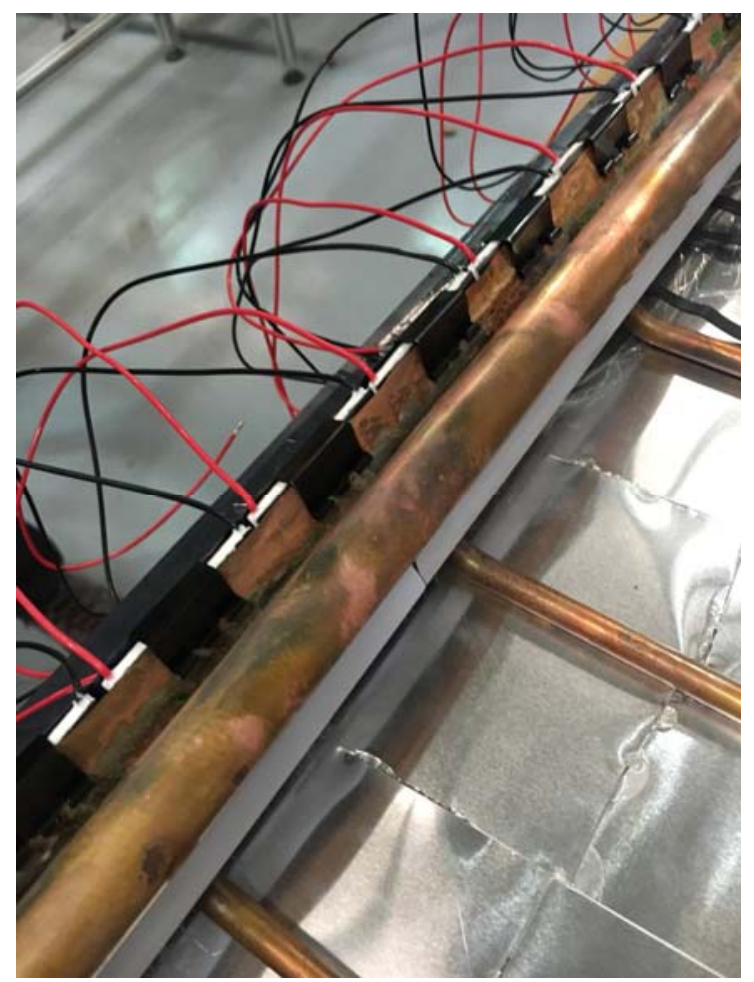

Fig. 4: Detail of the TEG and clamps installation

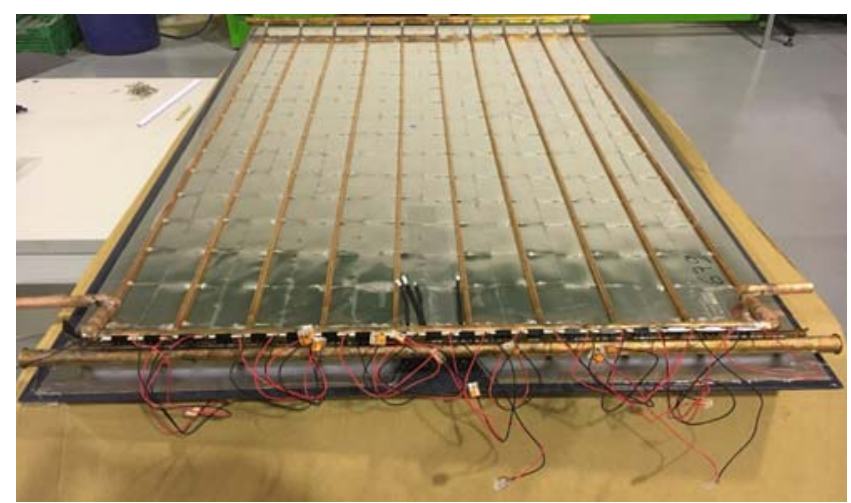

Fig.5: General view of TEG installation in the PVT module

For the temperature range of usual operation of PVT systems (low temperature: $\Delta \mathrm{T}$ between 40 and $100^{\circ} \mathrm{C}$, TEGs of $\mathrm{SnSb}$ have been selected.

In particular, TEG Modules TEG2-07025HT-SS have been installed in the prototype. The module withstands temperatures up to $190^{\circ} \mathrm{C}$ in the hot side. The $\mathrm{P}$ and $\mathrm{N}$ elements incorporated in this module offer the great heat transfer capability in a $40 \times 40 \mathrm{~mm}$ configuration. As long as a DT is applied to the module surfaces DC current will be generated. 


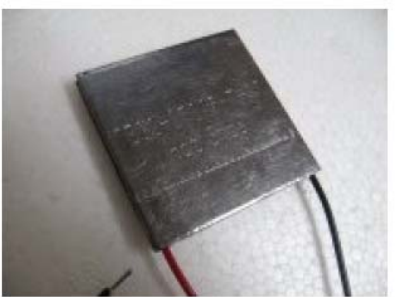

Geometric Characteristics Dimensions in millimeter
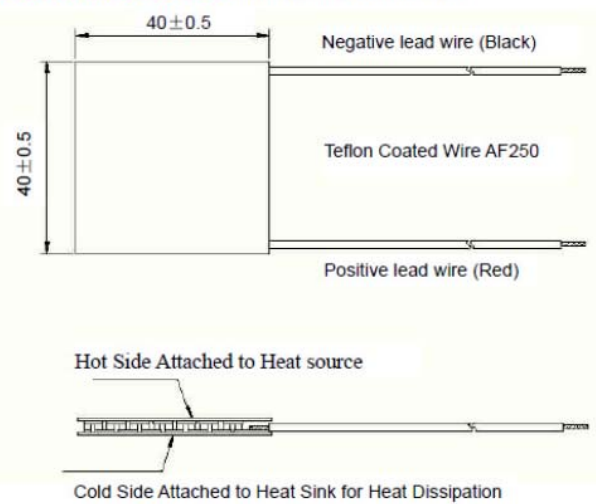

Fig. 6: Characteristics of the selected TEG

According to the manufactures, with the usual temperatures in PVTs, some 2W could be expected as a maximum.

\begin{tabular}{|c|c|l|c|}
\hline \multicolumn{3}{|l|}{ Power ratings at various DT's } & \multicolumn{1}{c}{} \\
\cline { 1 - 3 } $\begin{array}{c}\text { DT } \\
\text { Celsius }\end{array}$ & $\begin{array}{l}\text { Voltage } \\
\text { Match }\end{array}$ & $\begin{array}{l}\text { Current } \\
\text { Match }\end{array}$ & $\begin{array}{l}\text { Watts } \\
\text { Maximum }\end{array}$ \\
\hline 50 & .6 & 1.1 & .66 \\
\hline 80 & 1.0 & 2.0 & 2.00 \\
\hline 100 & 1.3 & 2.2 & 2.86 \\
\hline 120 & 1.4 & 2.4 & 3.36 \\
\hline 150 & 1.8 & 3.0 & 5.40 \\
\hline 170 & 1.9 & 3.2 & 6.08 \\
\hline 180 & 2.0 & 3.4 & 6.80 \\
\hline
\end{tabular}

Fig. 7: TEG Power rating at various DT's specifications

As the fluid moves through the PVT module changes its temperature from the inlet to the (colder) panel to the output (hotter) varying the temperature gradient to which the TEG modules undergo and therefore the electricity production varies. Current, voltage and average temperature data can be obtained in each of the zones. In addition, the electrical output of each zone will be treated with a maximum power point tracker for the power generation from the PV module and a variable match resistance for the TEG output to maximize the total production.

The behaviour and performance of the PVT + TEG modified panel will be analysed in front of an unmodified PVT panel for different ranges of temperatures and flow rates, which will be mounted in the same experimental installation. In this way, the influence of the TEG modules can be studied when they are integrated in a hybrid panel.

\section{Conclusion}

In this paper, the design, construction and start-up of an experimental installation of PVT+TEG modules has been presented. The modest additional electricity generated contributes to an improvement in the overall efficiency of the systems. The solution is simple and ease to incorporate in usual PVT modules. In a future work the influence of the irradiance, ambient temperature and temperature of the fluid can be studied. A model to determine the operating temperatures and estimate in a preliminary way the effect of the inclusion of the TEG in the behaviour of the panel will be developed. This model will serve as a basis to develop a TRNSYS type.

\section{Acknowledgements}

The authors would like to grate to Spanish Ministry of Science and Innovation and Spanish Ministry of Universities for funding the project "TEGBIOSOL Integration of thermoelectricgenerators (TEG) in solar PVT collectors and biomass boilers: testing and optimization in polygeneration schemes" (ref. RTI2018098886-A-I00)

\section{References}

[1] D. Li, Y. Xuan, Q. Li, H. Hong. Exergy and Energy analysis of photovoltaic-thermoelectric hybrid systems. Energy 126 (2017) 343-51.

[2] N. Dimri, A. Tiwari, GN Tiwari. Thermal modelling of semi-transparent photovoltaic thermal (PVT) with thermoelectric cooler (TEC) collector. Energy Conversion and Management 146 (2017) 68-77.

[3] EA Chávez- Urbiola, YV Vorobiev , LP Bulat . Solar hybrid systems with thermoelectric generators. Solar Energy 86 (2012), 369-78.

[4] E. Massaguer, A. Massaguer , L. Montoro , JR Gonzalez . Modeling analysis of longitudinal thermoelectric energy harvester in low temperature waste heat recovery applications. Applied Energy 140 (2015) 184-95.

[5] M. Fisac, FX Villasevil, A. M. López . High-efficiency photovoltaic technology including thermoelectric generation. Journal of Power Sources 252 (2014) 264-9.

[6] A. Rong, R. Lahdelma. Role of polygeneration in sustainable energy system development challenges and opportunities from optimization viewpoints. Renewable and Sustainable Energy Reviews 53 (2016) 363-72.

[7] K. Jana, A. Ray, MM Majoumerd, M. Assadi , S. De. Polygeneration as a future sustainable energy solution - A comprehensive review. Applied Energy 202 (2017) 88-111.

[8] F. Calise , M. Dentice d'Accadia , A. Piacentino A novel solar trigeneration system integrating PVT (photovoltaic / thermal collectors) and SW (seawater) desalination: Dynamic simulation and economic assessment. Energy 67 (2014) 129-48 [9] ME Demir, I. Dincer Development of an integrated hybrid solar thermal power system with thermoelectric generator for desalination and power production. Desalination 404 (2017) 5971.

[10] S. Islam, I. Dincer, BS Yilbas . Development, analysis and assessment of solar energy-based multigeneration system with thermoelectric generator. Energy Conversion and Management 156 (2018) 746-56. 